\title{
Characterization of Insulin-Like Growth Factor (IGF)-I-Receptor Binding Sites during In Vitro Transformation of Rat Hepatic Stellate Cells to Myofibroblasts
}

\author{
Arnfried Brenzel and Axel M. Gressner' ${ }^{1}$ )
}

Department of Clinical Chemistry and Central Laboratory, Philipps University, Marburg, Germany

Summary: Insulin-like growth factors are growth-promoting peptides structurally related to insulin which possess autocrine and paracrine activities. IGF-I is mainly synthesized in hepatocytes, but little is known about its paracrine action on hepatocyte-adjacent perisinusoidal hepatic stellate cells, the principal matrix producing precursor cell type in the liver. IGF-I might stimulate proliferation and phenotypical transformation of hepatic stellate cells into myofibroblasts, the cell type responsible for the excessive production of connective tissue elements during fibrogenesis. In this study we investigated the expression and function of the IGF-I receptor during transformation of isolated and cultured hepatic stellate cells. The respective stages of transformation of hepatic stellate cells were defined by determination of cellular smooth muscle iso- $\alpha$-actin and retinyl-palmitate content, respectively. IGF-I receptor protein decreased stage-dependently down to 0.5 at the 4th day and about 0.17 at the 8 th day. The number of IGF-I receptors was determined to be initially $1.3 \times 10^{5} / \mathrm{cell}$. Their quantity decreased to $0.8 \times 10^{5}$ sites $/ \mathrm{cell}$ (4th day) down to $0.5 \times 10^{5}$ sites/cell at the 7 th day and remained constant thereafter at $0.7 \times 10^{5}$ sites $/$ cell. Dissociation constants $\left(K_{\mathrm{D}}\right)$ for IGF-I range from $0.32-0.57 \mathrm{nmol} / 1$ showing constantly high receptor affinity. Northern blot analyses revealed distinct upregulation of IGF-I receptor mRNA level during culture. It is concluded that hepatocyte-generated IGF-I and/or IGF-I binding proteins are candidate mediators of hepatic stellate cell activation during the initial period of transformation to myofibroblasts. After completion of transformation the cell becomes relatively refractory to the action of IGF-I as judged from receptor density.

\section{Introduction}

The perisinusoidal hepatic stellate cell (HSC, also termined vitamin A storing cell, fat storing cell, or Ito cell) $(1,2)$ has attracted much interest because of its prominent pathophysiological role as the precursor cell type responsible for liver fibrogenesis (3-5). Adjacent to endothelial cells and closely connected to hepatocytes by microvilli contact (6), inflammatory stimuli activate the resting retinoid storing hepatic stellate cell to proliferate, to transform phenotypically into myofibroblasts (MFB), and to express and synthesize a wide variety of extracellular matrix components which accumulate during the development of fibrosis $(7-10)$. Activation of hepatic stellate cells is generally regarded as the crucial step in the molecular and cellular pathogenesis of fibrogenesis $(11,12)$.

The in situ transformation of hepatic stellate cells via transitional cells into myofibroblasts $(13,14)$ is characterized by ultrastructural changes and loss of specific cell contents (2). The concentration of retinyl-palmitate is reduced and the expression of smooth muscle iso- $\alpha-$

1) The financial support by grant Gr. 463/9-1 from the Deutsche Forschungsgemeinschaft is particularly acknowledged. actin is strongly upregulated (15-17). Similar to in situ activation of hepatic stellate cells in areas of necro-inflammation, a spontaneous transformation process is observed in isolated hepatic stellate cells grown on plain plastic support $(18,19)$.

The growth promoting, insulin related peptide, insulinlike growth factor (IGF)-I is a candidate paracrine mediator of stimulation of hepatic stellate cell proliferation and transformation (20). IGF- $\mathrm{I}^{2}$ ) is produced in significant quantities by hepatocytes $(21-26)$ and is functionally modulated by co-synthesized IGF binding proteins (27-29); thus, the hepatic stellate cell is constantly exposed to a relatively high concentration of IGF-I in the immediate microenvironment. It was suspected that the action of IGF-I on hepatic stellate cells might depend strongly on the quantity and quality of the IGF-I receptor, a tyrosine kinase receptor related to the insulin receptor $(30,31)$. In the present study, we established quantitative and qualitative measures of IGF-I receptor sites as a function of the respective stage of hepatic stel-

2) Abbreviation:

IGF-I insulin-like growth factor-I 
late cell transformation to get a more detailed insight into the functional mechanism by which IGF might mediate hepatic stellate cell activation. It was found that receptor affinity and quantity are differently regulated during hepatic stellate cell transformation, which offers an additional regulation of hepatic stellate cell activation at the level of IGF-I receptor expression.

\section{Materials and Methods}

\subsection{Chemicals and reagents}

Enzymes for hepatic stellate cell isolation, Dulbecco's modified Eagle medium (DMEM), fetal calf serum (FCS), smooth muscle iso- $\alpha$-actin antibodies, and human recombinant insulin-like growth factors-I/II (hIGF-l/hIGF-lI) were purchased from Boehringer Mannheim GmbH, Mannheim. Germany. Anti-hIGF-I rabbit antiserum (UB3-189) was a gift from Drs. Louis Underwood and Judson $J$. van Wy, Division of Pediatric Endocrinology, University of North Carolina, Chapel Hill, USA; rat cross-reactive mouse monoclonal human IGF-I receptor $\beta$-subunit antibody was a gift from Dr. Ken Siddle, Dept. of Clinical Biochemistry, University of Cambridge, UK. Rat IGF-I receptor cDNA was generously provided by Dr. Derek LeRoith, NIH; Bethesda, USA. Fluorescein isothiocyanate(FITC)-conjugated anti-mouse IgG was from Dakopatts, Hamburg, Germany. [3-125I]iodotyrosyl insulin-like growth factor-I (specific activity $74 \mathrm{TBq} / \mathrm{mmol}$ ) and the enhanced chemoluminescence Western blotting detection kit were obtained from Amersham Buchler, Braunschweig, Germany. X-OMAT AR autoradiography film was from Kodak.

\subsection{Isolation and culture of hepatic stellate cells}

The isolation and characterization of hepatic stellate cells was performed as described previously $(32,33)$. The purity of hepatic stellate cells was $>0.98$ after the first medium change. The plating efficiency reached $0.52-0.61$, and the viability of cells, assessed by trypan blue exclusion, was found to be $>0.95$ after $24 \mathrm{~h}$ and after $6 \mathrm{~d}$ of culture, respectively. For receptor binding studies, hepatic stellate cells were seeded with a density of $1.5 \times 10^{4} / \mathrm{cm}^{2}$ in 24-well culture plates $\left(2 \mathrm{~cm}^{2} /\right.$ well; Greiner $\mathrm{GmbH}$, Nürtingen, Germany) or for Northern and Western blotting experiments in culture flasks $\left(75 \mathrm{~cm}^{2}\right)$ and grown as monolayers in DMEM containing 0.1 fetal calf serum. Special care was taken to exclude nonspecific radioligand binding effects to culture well plastic surfaces and/or surface adherent IGF binding proteins derived from fetal calf serum supplement (34), by presaturating with excess RIA grade bovine serum albumin $\left(0.01,3 \mathrm{~h}, 37^{\circ} \mathrm{C}\right)$ before use. Medium changes were carried out at the $1 \mathrm{st}, 4$ th and 8 th day after seeding.

\subsection{Determination of cell proliferation}

The actual cell number at each stage of hepatic stellate cell transformation was indirectly determined by fluorometric measurement of the DNA content of two culture wells $\left(4 \mathrm{~cm}^{2}\right)$ in triplicate, using calf thymus DNA as a standard (35). DNA quantities were then correlated to phase contrast microscopic cell numerations.

\subsection{Estimation of expression of cellular smooth muscle} iso- $\alpha$-actin by indirect immunofluorescence

Cell layers were washed twice with ice-cold phosphate buffered saline (PBS), pH 7.4, then fixed using 0.05 (by vol.) acetic acid in ethanol. Three washing steps with phosphate buffered saline was followed by blocking of unspecific binding with $1: 2$ diluted fetal calf serum $(30$ min, $22^{\circ} \mathrm{C}$ ). Cells were then reacted with smooth muscle anti-iso- $\alpha$ actin $(1: 50)$ antibody in phosphate buffered saline containing 0.01 bovine serum albumin for 1 hour at ambient temperature on a rotating platform. The cells were washed again three times with phosphate buffered saline and then reacted with fluorescein isothiocyanate-conjugated anti-mouse $\operatorname{lgG}(1: 50$ in phosphate buffered saline, 0.01 bovine serum albumin, $1 \mathrm{~h}, 22^{\circ} \mathrm{C}$ ). After two final washes with distilled water, the cell layers of four culture wells $\left(8 \mathrm{~cm}^{2}\right.$, triple determination) were scraped off, suspended in distilled water and pooled. Subsequent fluorometric measurement was carried out in an SFM-25 spectrofluorometer (Kontron Analytical, Eching, Germany) at an excitation wavelength of $470 \mathrm{~nm}$, analysed at $520 \mathrm{~nm}$ emission wavelength. Immunofluorescence intensity was expressed as the complementary percentage value of the photomultiplier high voltage requirement to produce maximum sample fluorescence, compared to the absolute maximum value detected at the 11 th culture day. To confirm complete transformation of hepatic stellate cells, another reference value was taken at the 14 th culture day.

\subsection{Determination of cellular retinyl-palmitate content}

All preparations were performed under light protected conditions. For triplicate determination, cell layers of two culture wells $\left(4 \mathrm{~cm}^{2}\right)$ were washed twice with phosphate buffered saline, scraped off in $0.5 \mathrm{ml}$ phosphate buffered saline suspension volume, and stored at $-30^{\circ} \mathrm{C}$ until use. Retinoids were extracted with $n$-hexane after complete cell disruption by repeated freezing and thawing and protein precipitation with 0.5 (by vol.) ethanol. After phase separation (centrifugation at $600 \mathrm{~g}, 5 \mathrm{~min}, 4^{\circ} \mathrm{C}$ ), aliquots of the $n$-hexane phase were taken for HPLC analysis (RP-18 column Nucleosil 100-5-Si, Latek, Heidelberg, Germany; mobile phase $n$-hexane iso-propanol, $94+6$ (by vol.); flow rate $1.5 \mathrm{ml} / \mathrm{min}$; UV-detection at $330 \mathrm{~nm}$; $22^{\circ} \mathrm{C}$ ). The retinyl-palmitate concentration was calculated using the "External Standard Quantification" method of peak area integration of the recording integrator (Waters, Eschborn, Germany).

\subsection{Isolation of total RNA and Northern blot}

hybridization analysis of IGF-I receptor mRNA

Total cellular RNA was extracted from freshly isolated, eight day old cultured hepatic stellate cells according to Chomczynski \& Saachi (36). For Northern blot analysis, total RNA was separated using a denaturating 0.012 agarose, 0.06 formaldehyde gel followed by the blotting procedure described elsewhere (37).

\subsection{Sodium dodecyl sulphate-polyacrylamide gel electrophoresis (SDS-PAGE) and \\ Western blot analysis}

Cultures of differently transformed hepatic stellate cells (days 2, 4,8 ) were extracted on ice, using 0.02 sodium dodecyl sulphate electrophoresis sample buffer in the presence of protease inhibitors. Aliquots ( $5 \mathrm{~g} / 1$ protein) were subjected to sodium dodecyl sulphatePAGE ( 0.08 polyacrylamide) under non-reducing conditions using the discontinuous buffer system of Laemmli (38). Prestained molecular weight markers were used. For immunoblotting, the electrophoresed samples were transformed onto nitrocellulose by fast semi-dry electroblotting (200 $\mathrm{mA} / 8-20 \mathrm{~V}, 30-45 \mathrm{~min})$ using a synthetic carbon electrode blotting device (HLI, Landsberg, Germany) and incubated with specific primary antibodies against IGFI receptor (final dilution $1: 500$ ). Bound antibodies were detected using the Amersham enhanced chemoluminescence Western detection kit.

\subsection{Performance of the radioreceptor assay (RRA) and validation of rat hepatic stellate cell receptor specificity for hIGF-I by displacement and immunoneutralization studies}

To perform IGF-I displacement and IGF-I immunoneutralization experiments, we used hepatic stellate cells grown for 3 to 8 days in 24-well multidishes in the presence of 0.1 fetal calf serum supplemented medium. After aspiration of the culture medium, monolayers were washed twice with binding buffer $(128 \mathrm{mmol} / / \mathrm{NaCl}$, $5 \mathrm{mmol} / 1 \mathrm{KCl}, 1.2 \mathrm{mmol} / \mathrm{l} \mathrm{CaCl}, 1.2 \mathrm{mmol} / 1 \mathrm{MgSO}_{4}, 50 \mathrm{mmol} / \mathrm{l}$ 
HEPES, $\mathrm{pH} 7.4$, and 0.005 bovine serum albumin RIA grade) and incubated for 45 minutes at $37^{\circ} \mathrm{C}$ in binding buffer to allow complete incorporation of cell associated IGF. After equilibration for about $15 \mathrm{~min}$ at ambient temperature $\left(20-22^{\circ} \mathrm{C}\right)$, the assay volume was adjusted to $500 \mu \mathrm{l} /$ well with binding buffer, including $185 \mathrm{~Bq}$ of $\left[{ }^{125}\right.$ I]IGF-I. To verify IGF-I receptor specificity, IGF-I $(0.25,1,2.5,5,10,25,100 \mathrm{ng} /$ well $)$, IGF-Il $(1,5,50,500 \mathrm{ng} /$ well $)$ and insulin $(10,50,500,5000 \mathrm{ng} /$ well) were added as competing peptides. Ligand specificity was tested by immunoneutralization of [125I]IGF-I in the presence of different dilutions of anti-hIGF-I rabbit antiserum UB3-189. To avoid non-specific ligand adhesion to plastic surfaces of culture wells or attached IGF binding proteins derived from fetal calf serum, measurements of [ ${ }^{125}$ I]IGF-I displacement were carried out in plain culture dishes not presaturated or presaturated for $3 \mathrm{~h}$ at $37^{\circ} \mathrm{C}$ with $10 \mathrm{~g} / 1 \mathrm{RIA}$ grade bovine serum albumin both in the absence and presence of 0.1 (by vol.) fetal calf serum and/or $5 \mathrm{ng} /$ well IGF-I.

Incubations were performed for 3 hours at $20^{\circ} \mathrm{C}$ on a rotating platform and terminated by aspirating the supernatant, followed by immediate washings with ice cold binding buffer. Specifically bound radioactivity was then liberated from cell surfaces with 0.01 Triton X-100 in phosphate buffered saline for 15 minutes on a rotating platform $\left(\sim 180 \mathrm{~min}^{-1}, 22^{\circ} \mathrm{C}\right)$. Radioactivity was measured in a Berthold gamma-counter (EG \& G Berthold GmbH, Bad Wildbad, Germany).

\subsection{Quantification of number and affinity of IGF-I re- ceptors with the radioreceptor assay (RRA)}

At the 2nd, 4th, 7th, 9th and 11 th day after seeding, hepatic stellate cell monolayers in 24-well culture plates were processed as described in the previous section. Scatchard analyses and displacement calculation data, to ascertain dissociation constants $\left(K_{\mathrm{D}}\right)$ and binding capacity values, were derived from IGF-I binding curves, which were computed with the IBM-PC version of the LIGAND (Scafit) program (courtesy of Dr. P. J. Munson, NIH, Bethesda, MD, USA) (39).

\section{Results}

Culture of rat liver hepatic stellate cells seeded with low density leads to continuous cell proliferation and completely transformed myofibroblasts (fig. la-c). The initially homogenously spread hepatic stellate cells started to change their spherical cell shape with perinuclear lipid droplets at the 3rd day after seeding by flattening and irregular increase in diameter, indicating the beginning of the transformation process (fig. 1a). During the following days, the cells developed characteristic cellular extensions along with actin fibers. In parallel, the number and size of fat droplets decreased (fig. 1b). Between the 7th and 9th culture days, hepatic stellate cells reached subconfluency and nearly all of them had a completely transformed myofibroblastic phenotype with no fat droplets visible (fig. 1c).

These morphological changes were accompanied by two measurable modifications used frequently as indicators of hepatic stellate cell transformation. Expression of smooth muscle iso- $\alpha$-actin was monitored using the newly described fluorescein isothiocyanate-immunofluorescence assay, and cellular retinyl-palmitate content was determined by reverse phase HPLC (fig. 2). It could be shown that the different stages of cell transformation exhibit an antiparallel course of increasing actin expres-
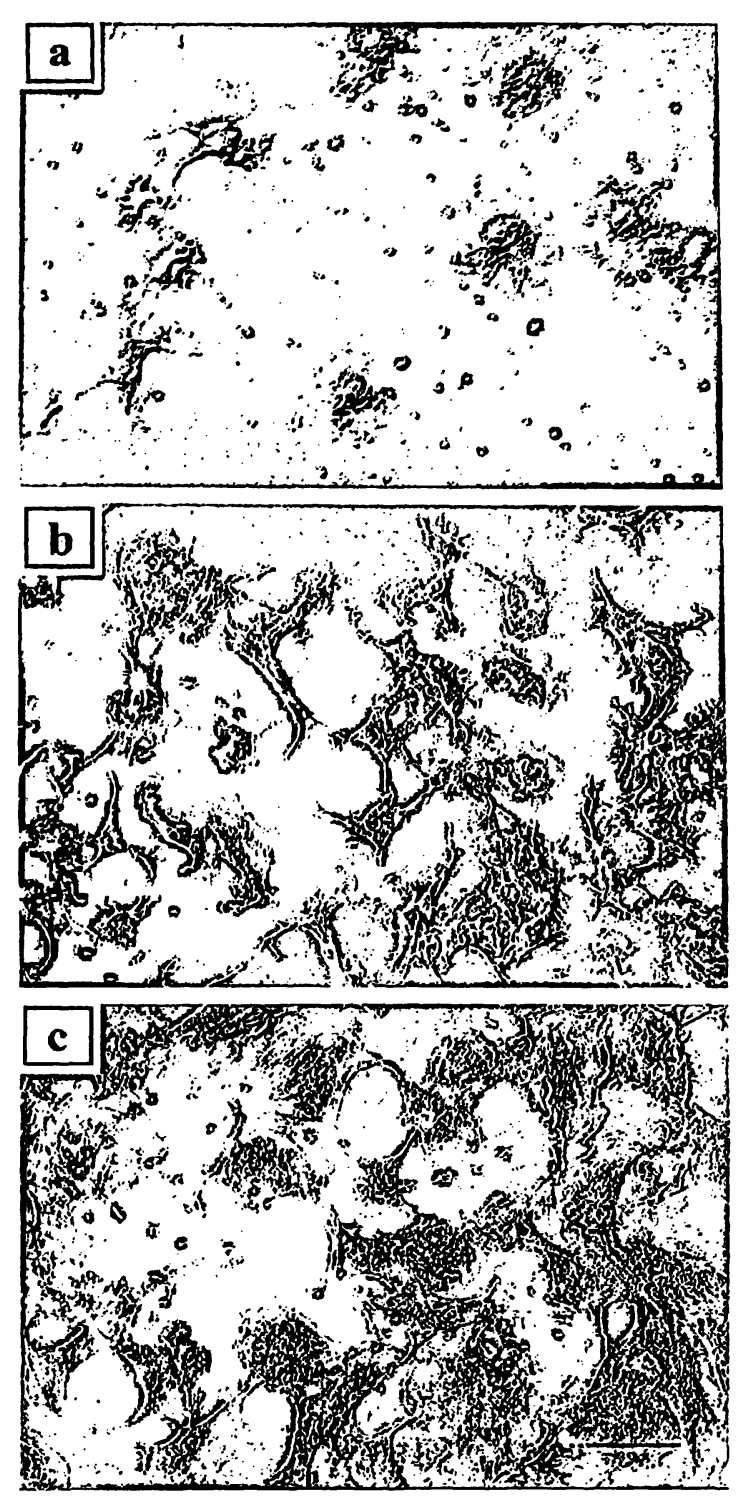

Fig. 1 Phase contrast micrographs of rat hepatic stellate cells (HSC) at

a) an early (2nd day),

b) an intermediate (5th day), and

c) a late (9th day) stage of transformation into myofibroblasts (bar represents $30 \mu \mathrm{m}$ ).

sion and decreasing amounts of retinyl-palmitate. Maximum changes in non-confluent hepatic stellate cells occured up to the 7th day after seeding, documented by a 0.77 increase of actin antibody related fluorescein isothiocyanate fluorescence, and a 0.52 decrease of retinylpalmitate content. The values ascribed to completely transformed cells were reached 4 days later, displaying finally 0.92 actin related fluorescence and an overall loss of 0.76 of retinyl-palmitate (fig. 2b). Interestingly, myofibroblasts still contain detectable amounts of retinylpalmitate, i.e. $3 \mu \mathrm{g} / 10^{6}$ cells, at the 14 th day, measured as described in continuous cultures from the quoted experiments.

The determination of IGF-I receptor protein expression in transforming hepatic stellate cells by Western blotting experiments revealed that type I IGF receptor (IGF-I-R) is present in all stages of transformation. The amount of IGFI receptor protein decreased from a maximum value at the 


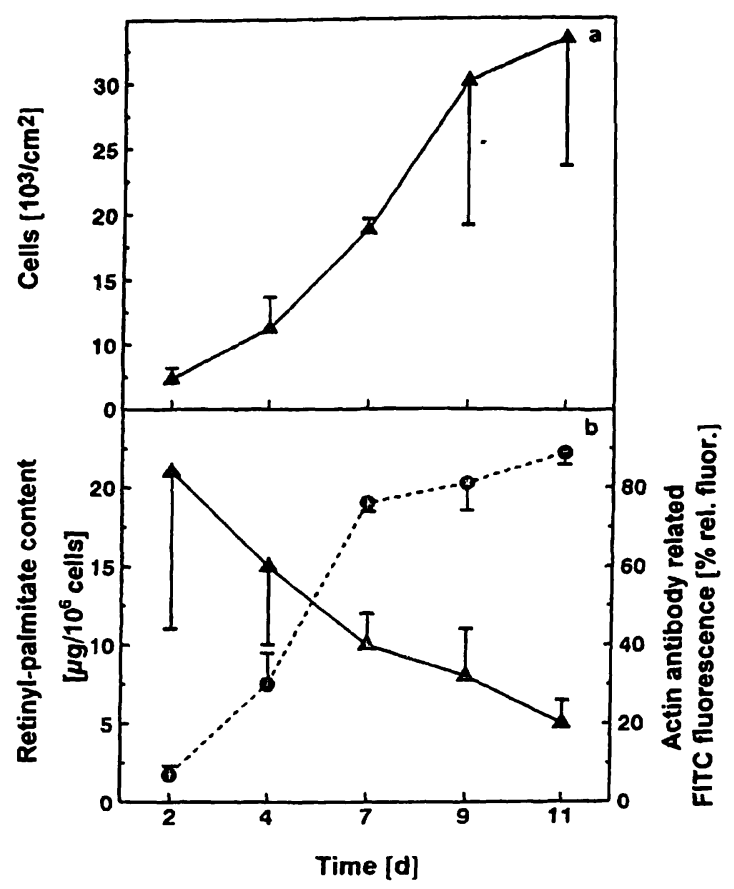

Fig. 2 a) Cell proliferation of spontaneously transforming hepatic stellate cells (HSC) from rat liver grown as non-confluent monolayers on uncoated plastic.

b) Concentration of cellular retinyl-palmitate content (-) and expression of $\alpha$-actin imeasured by antibody related fluorescein isothiocyanate fluorescence (---) in hepatic stellate cells during in vitro transformation.

2nd culture day down to about 0.5 at the 4th day and finally reached about 0.17 at the 8 th day (fig. 3 ).

To determine the specificity of IGF-I binding sites on rat hepatic stellate cells and to exclude non-specific IGF binding to plastic surfaces or to attached IGF binding proteins derived from fetal calf serum, exhaustive control experiments were carried out. As shown in figure 4, presaturation of plastic culture wells with bovine serum albumin generally resulted in a reduction of non-specific binding of the radiolabelled peptide hormone. In general, presaturation with bovine serum albumin decreased

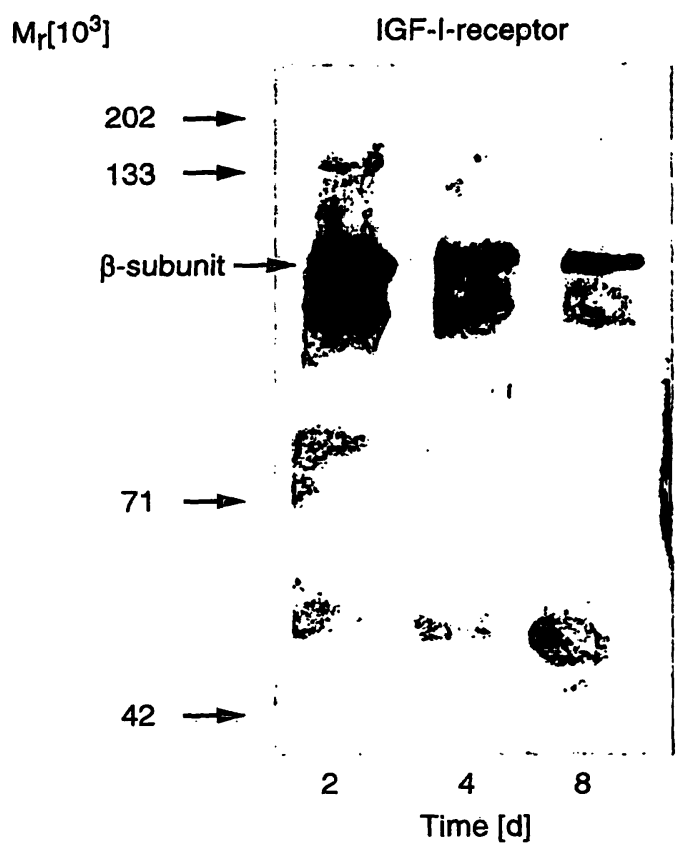

Fig. 3 Western blot analysis of cell extracts from 2, 4 and 8 day old cultured hepatic stellate cells (HSC) processed by sodium dodecyl sulphate-PAGE $(0.08)$ under non-reducing conditions, blotted and reacted with IGF-I receptor antibody directed against the $\beta$-subunit. Arrows indicate positions of molecular weight markers.

non-specific [ ${ }^{125}$ I]IGF-I binding by 0.5 to 0.6 (fig. 4). In contrast, pretreatment of unsaturated wells with 0.1 fetal calf serum enhanced non-specific binding of radiolabelled IGF-I by 0.1 , probably due to its content of IGF binding proteins. Again, this effect could be reduced by presaturation with bovine serum albumin (fig. 4).

Regular, dose-dependent displacement was achieved when adding increasing concentrations of unlabelled IGFI $(0.25$ to $100 \mathrm{ng} /$ well $)$ to 7 to 8 day old cultures of hepatic stellate cells, leading to 0.21 to 0.98 reduction of bound [ $\left.{ }^{125} \mathrm{I}\right] \mathrm{IGF}-\mathrm{I}$ (fig. 4, 5). Immunoneutralization of [25I]IGF-I by $1: 5000$ to $1: 200$ dilutions of anti-IGF-I rabbit antiserum displayed specificity of the respective

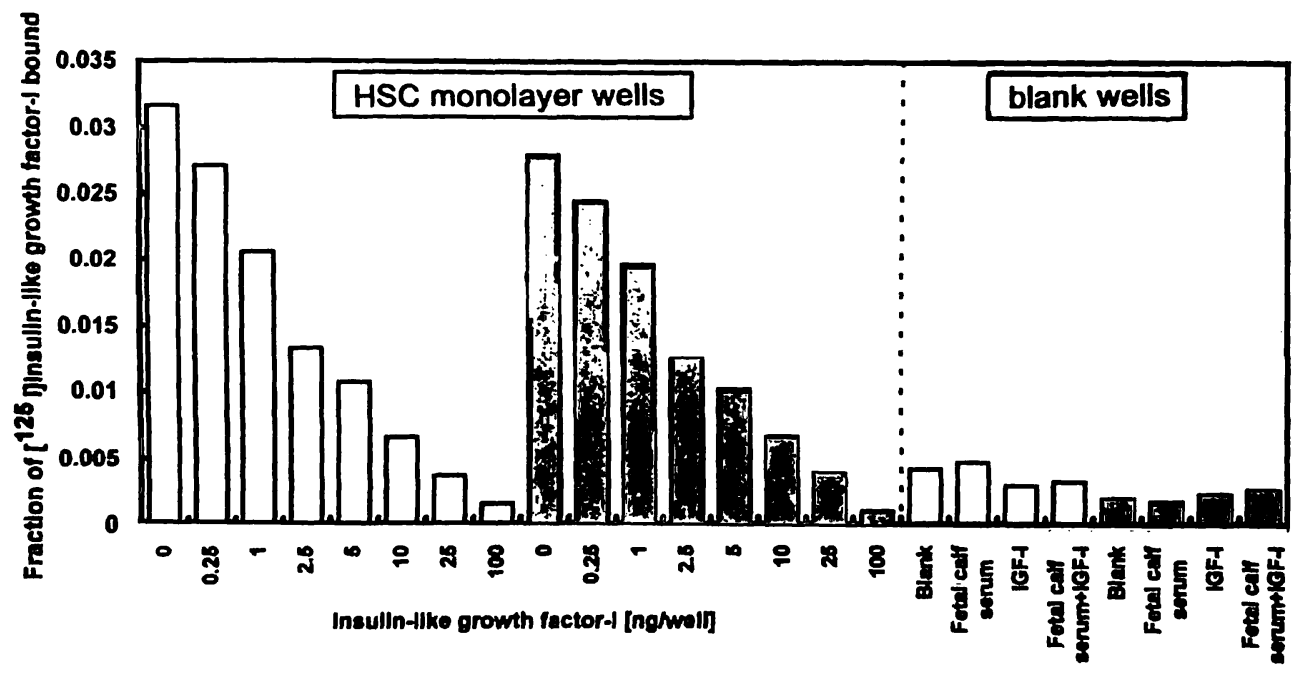

Fig. 4 Determination of binding of [ ${ }^{125}$ I] IGF-I (185 Bq/well) to culture wells and the hepatic stellate cells (HSC) monolayer surface, respectively, with (solid bars) and without (open bars) presaturation (bovine serum albumin RIA grade, $10 \mathrm{~g} / \mathrm{l}$ ). In blank experiments (right) fetal calf serum was added at $50 \mathrm{mg} / \mathrm{well}$ and IGF-I at $5 \mathrm{ng} /$ well, respectively. Values are means of triplicate determinations. 


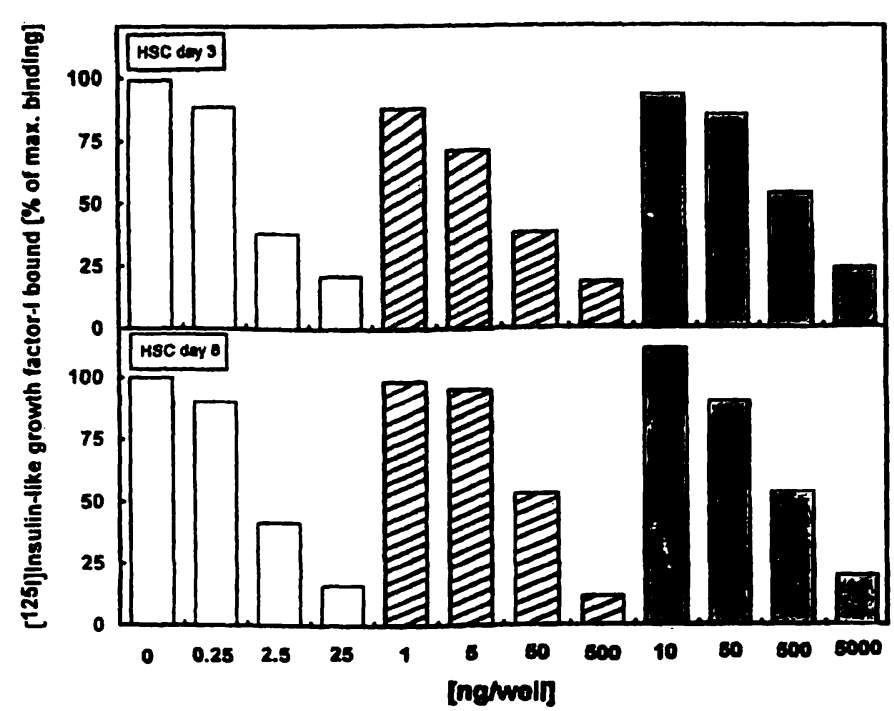

Fig. 5 IGF-I radioreceptor specificity assay carried out on early (3rd day) and transformed (8th day) rat liver hepatic stellate cells (HSC) displaying competitive displacement of [ $\left.{ }^{125} \mathrm{I}\right] \mathrm{IGF}-\mathrm{I}(185 \mathrm{~Bq} /$ well) by different concentrations (ng/well) of various ligands: IGFI (open bars), IGF-II (hatched bars), and insulin (solid bars). Values are means of triplicate determinations of one representative experiment.

ligand (data not shown). This was documented by a dosedependent decrease of ligand binding of 0.49 to 0.93 .

During all stages of hepatic stellate cell transformation, $\left[{ }^{125}\right.$ I]IGF-I binding was inhibited in a dose-dependent manner by increasing concentrations of IGF-I, as shown in typical displacement curves (fig. 5). Comparable competitive action of the related peptides IGF-II (20fold concentration) and insulin (200-fold concentration) characterized IGF-I receptor specificity in early (3rd day) and late (8th day) hepatic stellate cells (fig. 5, 6). Scatchard analyses from IGF-I binding data of primary and transformed hepatic stellate cells displayed absolutely linear and parallel plots (fig. 7), supporting the notion that $\left[{ }^{125} \mathrm{I}\right] \mathrm{IGF}-\mathrm{I}$ is bound to a single class of binding sites. The quality of the IGF-I receptor, expressed by $K_{\mathrm{D}}$ values, ranged from 0.32 to $0.57 \mathrm{nmol} / \mathrm{l} \mathrm{IGF}-\mathrm{I}$, indicating constantly high ligand affinity, whereas the quantity decreased from $1.3 \times 10^{5}$ sites $/$ cell $(0.2 \mathrm{amol} /$ cell) at the 2 nd culture day to $0.8 \times 10^{5}$ sites/cell $(0.13$ amol/cell) at the 4th day. Further reduction to less than 0.5 of the initial value at the 7 th day $\left(0.5 \times 10^{5}\right.$ sites/

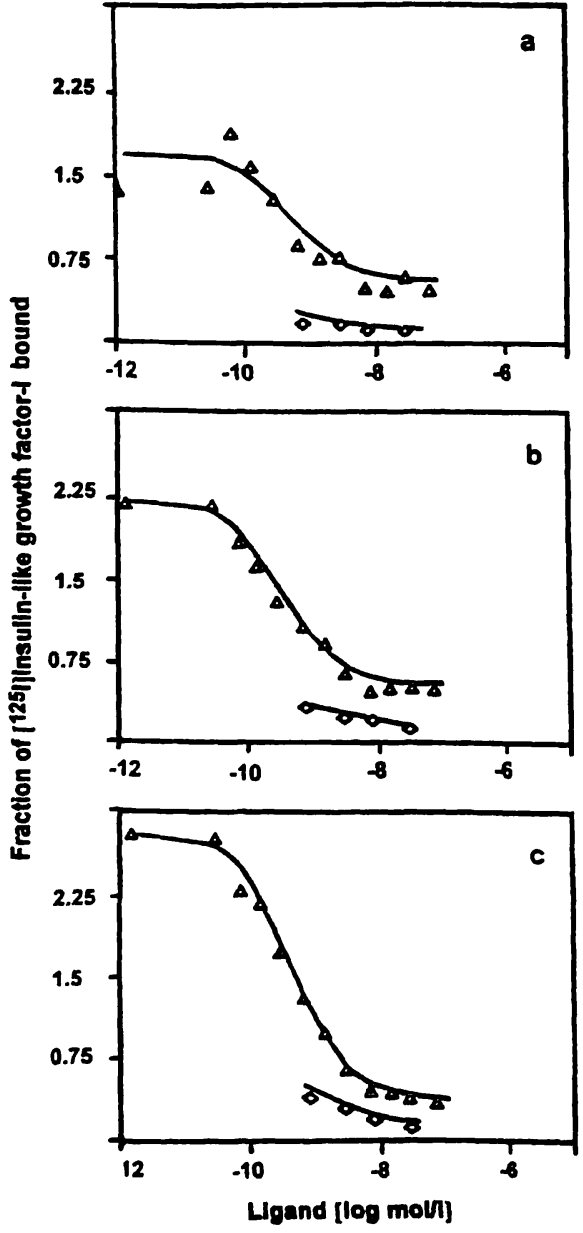

Fig. 6 Competitive displacement curves for IGF-I $(\Delta)$ binding to its corresponding receptor and for IGF-II binding to the IGF-I receptor $(\nabla)$ in

a) early (2nd day),

b) transforming (7th day) and

c) transformed (I1th day) hepatic stellate cells (HSC).

Values are means of triplicate determinations of at least two similar experiments.

cell, $0.08 \mathrm{amol} / \mathrm{cell}$ ) and then stable numbers of 0.7 $\times 10^{5}$ sites/cell $(0.11 \mathrm{amol} / \mathrm{cell})$ at the 9 th and 11 th day were measured (tab. 1). Though detectable amounts of the IGF-I receptor were found to be present in myofibroblasts, IGF-I receptor activity seems to be predominantly present in the early phase of hepatic stellate cell transformation.
Tab. 1 Specific binding affinities and total number of IGF-I binding sites in hepatic stellate cells during transîormation to myo- fibroblasts assessed by radioreceptor assay. Data represent triplicate determinations of at least two similar experiments.

\begin{tabular}{|c|c|c|c|c|c|}
\hline \multirow{2}{*}{$\begin{array}{l}\text { Culture time } \\
\text { [d] }\end{array}$} & \multirow{2}{*}{$\begin{array}{l}\text { Affinity constant } \\
\left(K_{\mathrm{A}}\right) \\
{[\mathrm{V} / \mathrm{nmol}]}\end{array}$} & \multirow{2}{*}{$\begin{array}{l}\text { Dissociation constant } \\
\left(K_{\mathrm{D}}\right) \\
{[\mathrm{nmol} / \mathrm{l}]}\end{array}$} & \multirow{2}{*}{$\begin{array}{l}\text { Binding capacity } \\
{[\mathrm{pmol} / \mathrm{l}]}\end{array}$} & \multicolumn{2}{|c|}{ Binding sites } \\
\hline & & & & [amol/cell] & {$\left[10^{5} /\right.$ cell $]$} \\
\hline 2 & 1.76 & $0.57 \pm 0.20$ & 6.77 & 0.21 & $1.26 \pm 0.40$ \\
\hline 4 & 2.42 & $0.41 \pm 0.18$ & 7.23 & 0.13 & $0.79 \pm 0.30$ \\
\hline 7 & 3.12 & $0.32 \pm 0.06$ & 5.68 & 0.08 & $0.47 \pm 0.07$ \\
\hline 9 & 2.75 & $0.36 \pm 0.05$ & 8.43 & 0.11 & $0.66 \pm 0.08$ \\
\hline 11 & 2.32 & $0.43 \pm 0.05$ & 10.80 & 0.11 & $0.68 \pm 0.06$ \\
\hline
\end{tabular}




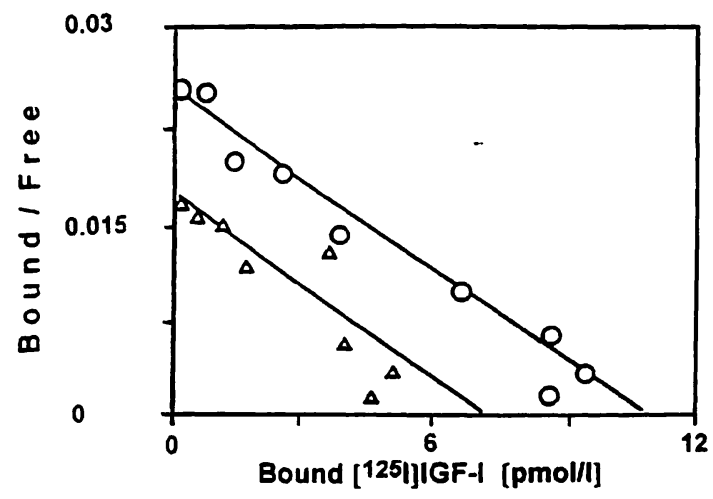

Fig. 7 Scatchard analysis of IGF-1 binding calculated for one binding site. Hepatic stellate cells at the 2 nd day $(\Delta)$ and 11 th day (o) were studied. Values are means of triplicate determinations of at least two experiments.

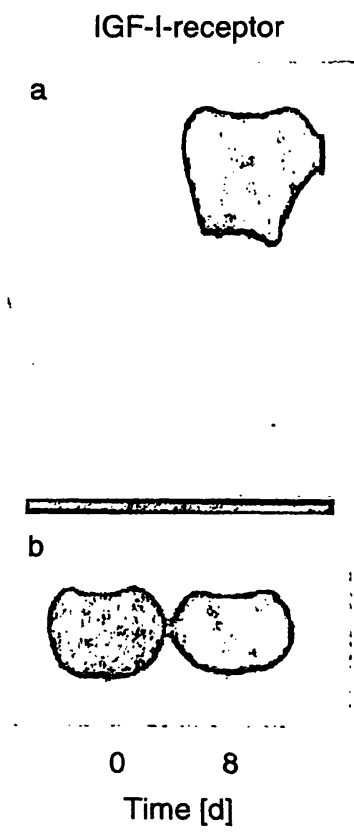

Fig. 8 Northern blot analysis of total cellular RNA of a) freshly isolated (0) and eight day old cultures of (8) hepatic stellate cells (HSC) probed for IGF-I receptor mRNA and b) for $\mathrm{S} 6 \mathrm{mRNA}$ used as internal standard.

In Northern blotting experiments, the steady state level of IGF-I receptor mRNA was very low in freshly isolated hepatic stellate cells (visible only after long exposure), but increased strongly in cells after 8 days in culture (fig. 8).

\section{Discussion}

Close anatomical connection of hepatic stellate cells with hepatocytes $(6,40)$, in combination with hepatic stellate cells stimulating activity present in hepatocyteconditioned media (41), strongly suggests participation of parenchymal liver cells in hepatic stellate cell activation in necro-inflammatory areas of the liver $(12,42)$. Our recent investigations show that IGF-I, which originates from cultured hepatocytes $(21-26,43)$, might be a candidate mediator of hepatic stellate cell activation (20). Additionally, its stimulatory potential can be en- hanced by specific IGF binding proteins $(27,28)$, secreted at least partially by hepatocytes (20). It was shown that hepatic stellate cells produce IGF as well as IGF binding proteins $(44,45)$, suggesting the potential of an additional, autocrine pathway in addition to hepatocyte-derived stimuli. Although IGF-I should be present in significant concentrations in the microenvironment of hepatic stellate cells, nothing is known about the cognate receptor of hepatic stelliate cells, which is crucial for the action of this cytokine (30). The present study was based on the hypothesis that the expression and function of IGF-I receptor might be subject to variation during hepatic stellate cell transformation as is the case for other cytokine receptors on hepatic stellate cells, e. g. for $\mathrm{PDGF}^{3}$ )-receptors (46). By regulation of the receptor level and affinity, IGF-I originating either from autocrine or paracrine loops might obtain stagedependent activity on hepatic stellate cells.

To obtain full transformation of primary cells within one batch of culture, low seeding densities were chosen. Cell proliferation kinetics assured that no cellular contact inhibition took place until cells reached subconfluency at the 9th to 11th day. Transformational stages were well documented by determining retinyl palmitate content and smooth muscle iso- $\alpha$-actin expression using a newly developed immunofluorescence semiquantification method. A strong rise of actin antibody related fluorescein isothiocyanate fluorescence was measured at the end of the culture period, combined with a decrease of cellular retinyl palmitate content to $5 \mu \mathrm{g} / 10^{6}$ cells; freshly seeded hepatic stellate cells contained about 20$30 \mu$ g (fig. 9).

Reliability of the radioreceptor assay using radioiodinated IGF (34) was achieved by presaturation of culture wells with RIA-grade bovine serum albumin. Non-specific binding of the radioactive ligand to charged plastic surfaces and/or adherent IGF binding proteins originating from fetal calf serum supplement (47) was thus greatly reduced. Ligand displacement and immunoneutralization experiments revealed specific IGF-I receptor binding sites present on hepatic stellate cells during all stages of transformation. This was supported by Northern blot analyses and in agreement with the findings of Zindy and co-workers (45), who documented expression of mRNAs for IGF-I-, IGF-II-, and insulin receptors in secondary cultures of hepatic stellate cells, i. e. myofibroblasts. Moreover, we could show that freshly isolated hepatic stellate cells possess only small amounts of IGFI receptor mRNA, and that mRNA upregulation obviously takes place early in culture as a distinct response to injurious stimuli in vitro. With special regard to functional characteristics, we have shown that expression of

3) $\mathrm{PDGF}=$ platelet derived growth factor 


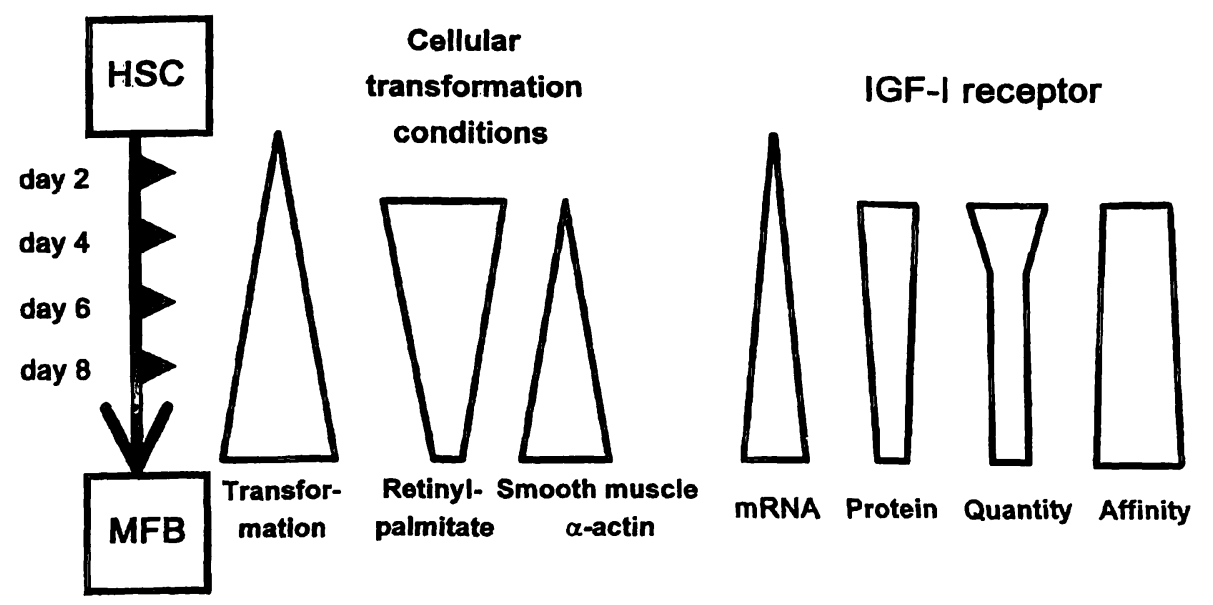

Fig. 9 Schematic presentation of the quantitative changes of the characteristics of IGF-I receptor in relation to major conditions of

IGF-I receptor is differently regulated over time. IGF-I is bound to a single class of binding sites during the whole course of transformation, which possess high and rather constant receptor affinity, as documented by dissociation constant values within a narrow range from 0.32 to $0.57 \mathrm{nmol} / 1$ IGF-I. Comparable results for IGF-I receptor affinities are quoted for 3T3-L1 adipocytes with a dissociation constant of $1.1 \mathrm{nmol} / 1$ (48) and human colon cancer cells with dissociation constants of 1.07$1.45 \mathrm{nmol} / \mathrm{l}$ and tumor membranes with dissociation constants of $0.62-1.13 \mathrm{nmol} / \mathrm{l}$ IGF-I (49). Specificity was established by competitive displacement of bound radioiodinated IGF-I by cold IGF-II and insulin which resulted in affinity constants to the IGF-I receptor being ten to a hundred times lower than that for IGF-I as reported by others (50). It is interesting that the specific cellular binding capacity for IGF-I decreased continuously during ongoing transformation, down to $0.7 \times 10^{5}$ IGF-I receptor/cell at the 9th culture day, representing approximately 0.5 of the initial IGF-I receptor density of $1.3 \times 10^{5}$ IGF-I receptor/cell. The latter number is comparable to $1.50-1.95 \times 10^{5}$ IGF-I binding sites per colon cancer cell (49). In agreement with the functional results, IGF-I receptor protein is comparably decreased as judged from Western blots. The decreasing number of IGF-I binding sites, in view of the mRNA upregulation for IGF-I receptor during transformation of hepatic stellate cells, suggests translational/posttranslational modulation of cell surface receptor expression in addition to transcriptional regulation.

In conclusion, our findings prove stage-dependent reduction of IGF-I receptor quantity, but not of affinity, during spontaneous transformation of hepatic stellate cells in culture as it is summarized in figure 9. Since this phenotypic change mimics hepatic stellate cell transformation in injured liver, it is suggested that at least early stages of transforming hepatic stellate cells in rat liver might receive paracrine stimuli via hepatocytederived IGF-I, the activity of which can be modulated cellular transformation of hepatic stellate cells (HSC) into myofibroblasts (MFB). The time-dependency is given on the $y$-axis.

by specific IGF binding proteins. In addition, the paracrine IGF stimulation might be supplemented by an autocrine amplification mechanism by which hepatic stellate cells produce their own set of IGFs and IGF binding proteins and, as shown here, specifically regulate affinities and quantities of the respective receptor species. It is proposed that the highly sensitive IGF and/or IGF binding protein regulatory system might be involved in the mechanism of hepatic stellate cell activation at the onset of fibrogenesis. An intriguing observation made in this study concerns the question by which mechanism hepatic stellate cells are kept quiescent in normal liver although they are exposed continually to mitogenic IGFI constitutively expressed and secreted by hepatocytes, and possess a significant quantity of high affinity IGF-I receptor, mainly in the untransformed status. As discussed previously, some antagonizing, inhibitory mechanisms keeping hepatic stellate cells in a resting condition have to be postulated (51). Potential inhibitory mechanisms effective in the liver, which are of great interest both clinically and theoretically, might concern the extracellular matrix surrounding hepatic stellate cells, the presence of soluble inhibitors, and "hepatocyte contacting processes" between hepatic stellate cells and hepatocytes (40). The latter structure might normally exert a kind of contact inhibition of hepatic stellate cells in situ, which is released during damage of hepatocytes, a prerequisite of the initiation of fibrogenesis in injured liver $(11,12)$. Ongoing studies are concentrated on these topics.

\section{Acknowledgements}

We thank Drs. L. Underwood and J. J. van Wyk (Div. of Pediatric Endocrinol., Univ. of North Carolina, Chapel Hill, USA) for the gift of anti-IGF-I rabbit antiserum, Dr. Ken Siddle (Dept. of Clinical Biochemistry, University of Cambridge, UK) for the gift of rat cross-reactive mouse monoclonal human IGF-I receptor $\beta$-subunit antibody, and Dr. Derek LeRoith (NIH, USA) for the generous gitt of rat IGF-I receptor cDNA. 


\section{References}

1. Aterman $\mathrm{K}$. The parasinusoidal cells of the liver: a historical account. Histochem J 1986; 18:279-305.

2. Blomhoff R, Wakc K. Perisinusoidal stellate cells of the liver: important roles in retinol metabolism and fibrosis. FASEB $J$ 1991: 5:271-7.

3. Horn T, Junge J, Christoffersen P. Early alcoholic liver injury. Activation of lipocytes in acinar zone 3 and correlation to degree of collagen formation in Disse space. J Hepatol 1986; $3: 333-40$.

4. Ballardini G, Fallani M, Biagini G, Bianchi FB, Pisi E. Desmin and actin in the identification of Ito cells and in monitoring their evolution to myofibroblasts in experimental liver fibrosis. Virchows Arch B Cell Pathol 1988; 56:45-9.

5. Tanaka Y, Nouchi T, Yamane M, Irie T, Miyakawa H, Sato C, et al. Phenotypic modulation in lipocytes in experimental liver fibrosis. J Pathol 1991; 164:273-8.

6. Takahashi-Iwanaga H. Fujita T. Application of an $\mathrm{NaOH}$ maceration method to a scanning electron microscopic observation of Ito cells in the rat liver. Arch Histol Jap 1986; 49:349-57.

7. Bissell DM. Lipocyte activation and hepatic fibrosis. Gastroenterology 1992; 102:1803-5.

8. Bissell DM, Friedman SL, Maher JJ, Roll FJ. Connective tissue biology and hepatic fibrosis: report of a conference. Hepatology 1990; 11:488-98.

9. Gressner AM. Liver fibrosis: perspectives in pathobiochemical research and clinical outlook. Eur J Clin Chem Clin Biochem $1991 ; 29: 293-311$.

10. Ramadori G. The stellate cell (Ito-cell, fat storing cell, lipocyte, perisinusaidal cell) of the liver. Virchows Arch B Cell Pathol 1991; 61:147-58.

11. Gressner AM, Bachem MG. Molecular mechanisms of liver fibrogenesis - a homage to the role of activated fat-storing cells. Digestion 1995; 56:335-46.

12. Gressner AM. Perisinusoidal lipocytes and fibrogenesis. Gut 1994; 35:1331-3.

13. Mak K, Leo MA, Lieber CS. Alcoholic liver injury in baboons: transformation of lipocytes to transitional cells. Gastroenterology $1984 ; 87: 188-200$.

14. Mak KM, Lieber CS. Lipocytes and transitional cells in alcoholic liver disease: a morphometric study. Hepatology 1988; 8:1027-33.

15. Rockey DC, Friedman SL. Cytoskeleton of liver perisinusoidal cells (lipocytes) in normal and pathological conditions. Cell Motil Cytoskeleton 1992; 22:227-34.

16. Rockey DC, Boyles JK, Gabbiani G, Friedman SL. Rat hepatic lipocytes express smooth muscle actin upon activation in vivo and in culture. J Submicrosc Cytol Pathol 1992; 24:193-203.

17. Schmitt-Gräff A, Kruger S, Bochard F, Gabbiani G. Modulation of alpha-smooth muscle actin and desmin expression in perisinusoidal cells of normal and diseased human livers. Am J Pathol 1991; 138:1233-42.

18. Gressner AM. Time-related distribution profiles of sulfated glycosaminoglycans in cells, cell surfaces and media of cultured rat liver fat storing cells. Proc Soc Exp Biol Med 1991; 196:307-15.

19. Geerts A, Vrijsen R, Rauterberg J, Burt A, Schellinck P, Wisse E. In vitro differentiation of fat storing cells parallels marked increase of collagen synthesis and secretion. J Hepatol 1989; 9:59-68

20. Gressner AM, Brenzel A, Vossmeyer T. Hepatocyte-conditioned medium potentiates insulin-like growth factor-(IGF) 1 and -2 stimulated DNA synthesis of cultured fat storing cells. Liver 1993; 13:86-94.

21. Scott CD, Martin JL, Baxter RC. Production of insulin-like growth factor I and its binding protein by adult rat hepatocytes in primary culture. Endocrinology 1985; 116:1094-101.

22. Scott CD, Martin JL, Baxter RC. Rat hepatocyte insulin-like growth factor I and binding protein: effect of growth hormone in vitro and in vivo. Endocrinology 1985; 116:1102-7.

23. Norstedt $G$, Moeller $C$. Growth hormone induction of insulinlike growth factor I messenger RNA in primary cultures of rat liver cells. Endocrinology 1987; 115:135-9.
24. Neste van L, Husman B, Moeller C, Andersson G, Norstedt G. Cellular distribution of somatogenic receptors and insulin-like growth factor-I mRNA in the rat liver. J Endocrinol 1988; 119:69-74.

25. Kachra Z, Barash I, Yannopoulos C, Khan MN, Guyda HJ, Posner BI. The differential regulation by glucagon and growth hormone of insulin-like growth factor (IGF)-I and IGF-binding proteins in cultured rat hepatocytes. Endocrinology 1991; 128:1723-30.

26. Johnson TR, Blossey BK, Denko CW, Ilan J. Expression of insulin-like growth factor-I in cultured rat hepatocytes: effects of insulin and growth hormone. Mol Endocrinol 1989; 3:580-7.

27. Elgin RG, Busby WH, Clemmons DR. An insulin-like growth factor (IGF) binding protein enhances the biologic response to IGF-I. Proc Natl Acad Sci USA 1987; 84:3254-8.

28. Blum WF, Jenne EW, Reppin F, Kietzmann K, Ranke MB, Bierich JR. Insulin-like growth factor-I (IGF-I)-binding protein complex is a better mitogen than free IGF-I. Endocrinology $1989 ; 125: 766-72$.

29. Mohn KL, Melby AE, Tewari DS, Laz TM, Taub R. The gene encoding rat insulin-like growth factor binding protein 1 is rapidly and highly induced in regenerating liver. Mol Cell Biol $1991 ; 11: 1393-401$.

30. Rubin R, Baserga R. Insulin-like growth factor-I receptor its role in cell proliferation, apoptosis, and tumorigenicity. Lab Invest 1995; 73:311-31.

31. Neely EK, Beukers MW, Oh Y, Cohen P, Rosenfeld RG. Insulin-like growth factor receptors. Acta Paediatr Scand 1991; 372:116-23.

32. Schäfer S, Zerbe O, Gressner AM. The synthesis of proteoglycans in fat storing cells of rat liver. Hepatology 1987; 7:680-7.

33. Meyer DH, Bachem MG, Gressner AM. Modulation of hepatic lipocyte proteoglycan synthesis and proliferation by Kupffer cell-derived transforming growth factors type-beta 1 and typealpha. Biochem Biophys Res Commun 1990; 171:1122-9.

34. Duclos MJ, Goddard C. Pitfalls in insulin-like growth factor (IGF) receptor binding studies using cells in monolayer culture. Horm Metab Res 1991; 23:562-4.

35. Labarca C, Paigen K. A simple, rapid, and sensitive DNA assay procedure. Anal Biochem 1980; 102:344-52.

36. Chomczynski P, Sacchi V. Single-step method of RNA isolation by acidic guanidinium thiocyanate-phenol-chloroform extraction. Anal Biochem 1987; 162:156-9.

37. Noegel A, Metz BA, Williams $\mathrm{KL}$. Developmentally regulated transcription of Dictyostelium discoideum plasmid Ddpl. EMBO 1985; 4:3797-803.

38. Laemmli UK. Cleavage of structural proteins during the assembly of the head of bacteriophage T4. Nature 1970; 227:680-5.

39. Munson PJ. Munson PJ, editor. A user's guide to LIGAND. Data analysis and curve-fitting for ligand binding experiments. Bethesda: Laboratory of Theoretical and Physical Biology National Institute of Child Health and Human Development, National Institutes of Health. Bethesda, 1987.

40. Wake K. Perisinusoidal fat-storing cells of the liver. In: Surrenti C, Casini A, Milani S, Pinzani M, editors. Fat-storing cells and liver fibrosis. [Proceedings of the International Falk Symposium.] Falk Symposium 71 ed. Dordrecht: Kluwer Academic Publishers, 1993:1-10.

41. Gressner AM, Lotfi S, Gressner G, Lahme B. Identification and partial characterization of a hepatocyte-derived factor promoting proliferation of cultured fat storing cells (parasinusoidal lipocytes). Hepatology 1992; 16:1250-66.

42. Gressner AM, Bachem MG. Cellular communications and cell-matrix interactions in the pathogenesis of fibroproliferative disease: liver fibrosis as a paradigm. Ann Biol. Clin 1994; 52:205-26.

43. Lamas E, Zindy F, Seurin D, Guguen-Guillouzo C, Brechot C. Expression of insulin-like growth factor-II and receptors for insulin-like growth factor-II, insulin-like growth factor-I and 
insulin in isolated and cultured rat hepatocytes. Hepatology $1991 ; 13: 936-40$.

44. Pinzani M, Abboud HE, Aron DC. Secretion of insulin-like growth factor-I and binding proteins by rat liver fat storing cells: regulatory role of platelet-derived growth factor. Endocrinology 1990; 127:2343-9.

45. Zindy F, Lamas E, Schmidt S, Kirn A, Brechot C. Expression of insulin-like growth factor-II (IGF-II) and IGF-II, IGF-I and insulin receptors messenger RNAs in isolated non-parenchymal rat liver cells. J Hepatol 1992; 14:30-4.

46. Friedman SL, Arthur JP. Activation of cultured rat hepatic lipocytes by Kupffer cell conditioned medium. J Clin Invest 1989; 84:1780-5.

47. Bylund DB. A practical guide for receptor binding. Biotech Update Du Pont 1992; 7:19-21.

48. Weiland $M$, Bahr F, Höhne M, Schürmann A, Ziehm D, Joost HG. The signaling potential of the receptors for insulin and insulin-like growth factor 1 (IGF-I) in 3T3-L1. Adipocytes: comparison of glucose transport activity, induction of oncogene c-fos, glucose transporter mRNA, and DNA synthesis. J Cell Physiol 1991; 149:428-35.
49. Guo YS, Narayan S, Yallampalli C, Singh P. Characterization of insulin-like growth factor-I receptors in human colon cancer. Gastroenterology 1992; 102:1101-8.

50. Heinz-Erian P, Kessler U, Funk B, Gais P, Kiess W. Identification and in situ localization of the insulin-like growth factor II/mannose-6-phosphate (IGF-II/M6P) receptor in the rat gastrointestinal tract: comparison with the IGF-I-receptor. Endocrinology 1991; 129:1769-78.

51. Gressner AM, Lahme B, Brenzel A. Molecular dissection of the mitogenic effect of hepatocytes on cultured hepatic stellate cells. Hepatology 1995; 22:1507-18.

Received January 22, 1996

Corresponding author: Prof. Dr. A. M. Gressner, Abteilung für Klinische Chemie und Zentrallaboratorium, Klinikum der Philipps-Universtität, Baldingerstraße, D-35033 Marburg, Germany 
